\title{
MEASURING SELF-RELIANCE IN REFUGEE CAMPS
}

by Dr. Anna-Mara Schön, Celina Borchert, Luisa Kunst (Preprint - January 2021)

\begin{abstract}
The concept of "self-reliance" is widespread, but only recently there have been initiatives that not only use the term "self-reliance", but also try to measure it - rather for refugees outside than in refugee camps, though. Thus, the "Camp Performance Indicator (CPI) system" was developed and applied to different case studies. This paper examines the level of self-reliance for camps in Jordan (Zaatari camp and Azraq camp) and Kenya (Dadaab Complex), but also for refugee settlements in Uganda (Nakivale and Bidibidi) and simultaneously tests the CPI, a tool consisting of 109 indicators. Applying the CPI revealed that the level of self-reliance is generally low in the five camps and settlements studied, backing up our initial hypothesis.
\end{abstract}

Key words: Self-reliance, refugees, refugee camps, performance measurement, human rights

\section{INTRODUCTION}

Refugees are a highly oppressed and marginalised group, often even worse when living in camps (Gray Meral 2020; Schön 2020; United Nations Economic and Social Council 2016; Young 1992). In many cases, deprived of their human rights, located in remote areas and without access to the local labour market, encamped refugees have no other opportunity than turning to negative coping mechanisms to survive, including sex work, child labour, crime and dangerous work in the informal sector (UNHCR 2014). The concept of self-reliance is perceived and discussed among practitioners and researchers as an important instrument against the impoverishment of refugees, yet under prevailing conditions becoming self-reliant is in most cases unimaginable. 
Along with the rise in the proportion and numbers of the urban refugee population in the twentyfirst century, the focus in academia shifted from rural and camp settings to urban ones (Field, Tiwari, Mookherjee 2020; Skran, Easton-Calabria 2020; Slaughter 2019; UNHCR 2019b). In contrast, this research concentrates on camp settings, as about 2.6 million refugees live in camps (USA for UNHCR 2020).

Herein, present work describes the development of the denoted Camp Performance Indicator system (CPI), which was leveraged to measure the case studies from Jordan, Kenya and Uganda. Following, to test the CPI and examine the factors necessary to reach self-reliance, we apply the CPI to these five settlements/camps which, apart from Nakivale, are among the largest refugee camps in the world (USA for UNHCR 2020): Zaatari and Azraq camp in Jordan, probably the most modern camps worldwide, Dadaab in Kenya, existing for decades (Borchert 2019), as well as Nakivale and Bidibidi settlements in Uganda due to the country's liberal refugee policies (Kunst 2020). The application of the CPI to the case studies reveals that the CPI is a useful concept to identify and cluster information and indicators desk-based and in a structured way to assess the level of self-reliance in a camp or settlement, though not by computing an index, but in a systematic, descriptive way.

\section{SELF-RELIANCE IN REFUGEE CAMPS}

Despite self-reliance being praised as the desirable goal for individual refugees and their communities, a range of scholars finds the concept valuable, but its conceptualisation and practice flawed. Criticism extends to a too narrow focus on market-based solutions (Skran, EastonCalabria 2020), aiming at rather benefitting refugee hosting areas than refugees (Kaiser 2006), its application as cost-effective exit strategy (Easton-Calabria, Omata 2018) or simply to reduce material assistance (Hunter 2009).

In 2014, UNHCR published a revised definition: 
Self-reliance is the ability of an individual, household or community to meet essential needs and to enjoy social and economic rights in a sustainable manner and with dignity. By becoming self-reliant, refugees and displaced persons lead active and productive lives and are able to build strong social, economic and cultural ties with their host communities. Self-reliance can assist in ensuring that persons of concern are better protected by strengthening their capacity to claim their civil, cultural, economic, political and social rights. (UNHCR 2014, p.7)

Leading refugees towards self-reliance is a goal many international agencies pursue. Reasons therefore are manifold: A high level of self-reliance among refugees is beneficial to humanitarian organisations, facing budgetary shortfalls and a rising number of crises and, thus, cannot afford any longer to build their programmes only on assistance and in-kind donations (ALNAP 2015; UNHCR 2005). By reducing dependencies and creating self-reliance among refugees, humanitarian budgets are eased (UNHCR 2014). Further, human beings, in general, do not want to depend on aid (Leeson et al. 2020; Yunus 2018). Dependence on aid often goes hand in hand with poverty - a wide-spread problem among refugees and in refugee camps, leading to the development of physical and mental health problems, and social stigmatisation, among others (Oschmiansky 2010; van Damme 1995). If not allowed to work legally, people find activities operating outside the law, e.g., by working illegally or informally, creating or participating in parallel economies not or to a lesser extent stimulating local economies (UNHCR 2012; Betts 2014).

Thus, the goal must be - at least - to facilitate livelihood opportunities for refugees, but better to reach a high level of self-reliance among refugee communities in and outside of camps. Especially in camps, this objective is difficult to reach, though, thanks to prevailing conditions: Besides their isolated location in low populated areas, camps are also criticised for restricting the residents' movement by fences and the need for exit permissions (Turner 2016; Werker 
2007; Diken 2004). Remote locations are often chosen by host governments in border zones with security problems to avoid negative impacts on their communities (Bulley 2017) - though the negative impact is suffered mostly by the refugees. They lack access to infrastructure, work opportunities and markets, so they impoverish quickly and face difficulties to establish livelihood activities (Jahre et al. 2018; Corbet 2016; Abdi 2008). Reaching out to other communities is problematic, because transportation to the next market or city is costly or simply not available (Turner 2016; Diken 2004; Werker 2002). Police and immigration authorities harass and discriminate refugees and restrict their freedom of movement. Refugees must pay bribes more often than locals, for example, due to missing or (apparently) invalid documentation or because of unrecognised or not respected human rights (UNHCR 2012). Additional to security issues around or within camps, constrained access to markets and transportation means, limited natural resources, etc., also internal factors play a crucial role. Observable factors are a mismatch between labour markets and refugees' skills, lack of motivation to start new but uncertain livelihood activities, resistance coming from refugees to engage in livelihood opportunities to not jeopardise their chance for resettlement, or even the mind-set of field operatives fearing job loss when creating self-reliance among refugees, to name just a few (Schön 2020, pp.170-217).

Even though camp management is able to overcome at least some of those hurdles and enables self-reliance among a higher percentage of the camp labour force, challenges to measure and thus, make this success visible are equally abundant: lack of transparency due to no or only partial access to collected data by partners or the public, low quality of data because of low motivation of field operatives to gather data and "guesstimating", lack of cooperation, visions and strategy plans of organisations impeding successful project management in the field are reasons complicating the application of measuring tools (Schön 2020, pp.67-70). Based on these challenges, the assumption that the level of self-reliance in refugee camps is rather low, 
even in modern camps, is quickly drawn. To test this hypothesis a suitable tool was needed and thus, developed, and subsequently verified on case studies.

\section{THE CAMP PERFORMANCE INDICATOR SYSTEM}

A performance measure (indicator) is the metric used to quantify the efficiency and/or effectiveness of an action, whereas a performance measurement system is the set of metrics to quantify the efficiency and effectiveness of actions (Neely et al.1995). Performance measurement frameworks clarify boundaries, specify dimensions and show the relationship between the different dimensions (Rouse, Putterill 2003).

Thus, frameworks are the base for developing performance measurement systems. As a starting point, to assess self-reliance in refugee camps, the focus was first on infrastructure and services (Author et al. 2018). Concentrating only on these factors quickly proved to be too short. As there was no advanced measurement method available at that time, the CPI framework was developed, a concept based on the UNHCR 2014 definition on self-reliance as well as literature findings (Figure 1 - CPI framework). The CPI framework graphically represents the following assumption: It is important to highlight that the tool concentrates on the "desired labour force", including only those people able to and seeking paid work, excluding children and people not able to work due to trauma, vulnerability, child care activities, etc. Those people must remain supported (Skran, Easton-Calabria 2020). If people are able to pay their own bills, have emergency funds and may even be able to send remittances to family members and if, in addition, they can and are socially and/or politically active as well as can provide their children with good education, they are likely to be described as self-reliant. On base of this framework, we identified a set of indicators, which became the CPI System.

At that stage of research, interesting indicator sets started to be published, but testing phases were only at the beginning, still lacking complete published datasets. This gap has been closed 
by now, especially the Self-Reliance Index by RefugePoint (2020), the Well-Being and Adjustment Index presented in Leeson et al. (2020) as well as the conceptual framework by Betts et al. $(2018 ; 2020)$ represent innovative and promising attempts to assess self-reliance of refugees in different urban and camp settings.

To build a robust list of indicators to measure self-reliance, big and complete datasets of similar fields had to be used. Thus, the World Bank Database was considered as a starting point. The World Bank maintains 68 different databases, including World Development Indicators (1,575 indicators), Gender Statistics (631 indicators), Jobs Statistics (167 indicators) and SDG Statistics (348 indicators) (The World Bank 2018a), which were all taken into account. The World Bank's primary indicator collection of development indicators is the WDI dataset. The data is compiled by officially recognised international sources and is the most accurate source of its kind. To reduce the number of available indicators of the four indicator collections, correlation analysis was used, including only indicators correlating highly ((-1) to $(-0.5))$ with poverty (Schön 2020, pp.80-81). Poverty indicators (Poverty headcount ratio at national poverty lines (\% of population) and Poverty headcount ratio at $\$ 1.90$ a day (2011 PPP) (\% of population); (The World Bank 2018a)) were used, as it was assumed that poor people are hardly self-reliant in the sense of the UNHCR (2014) definition given above (Schön 2020). Relying on poverty indicators could only be a starting point, as it cannot be equated with self-reliance. The result of the correlation analyses of World Bank indicators and poverty indicators consisted of 290 indicators of which 133 were selected as potentially useful in a camp context and for a comparison with by then existing indicators, including the since mid-2018 obtainable information on the SRI as well as on the study of Betts et al. (2018). In total, indicators from 11 tools, reports, or concepts ( $c f$. Table 1 and Supplemented Information A) were extracted and compared with each other, revealing many similarities, although regarding the names of the categories used by each tool. Based on the findings of the World Bank correlation analyses, the comparison with the newest tools as well as judgements for the inclusion of each indicator based on literature, 
the final number of CPI indicators adds up to 109 indicators, plus sub-indicators ( $c f$. Supporting Information A and B).

The main motivation to create the CPI was to create transparency, to track the increase or decrease of self-reliance in a refugee camp, but also to reveal which interventions, infrastructure and services provided in and around a refugee camp impact the level of self-reliance (Schön 2020, pp.91-92). All indicators were sorted in three different groups:

A) Exogenous factors: Indicators revealing background information of the community, such as demographic data, traditions, skills and education acquired in the home country as well as other factors affecting positively or negatively the level of self-reliance; on these indicators and factors camp management cannot act upon or only marginally

B) Enabling factors: Factors/indicators affecting positively or negatively the level of selfreliance; on these indicators and factors camp management can act upon

C) Outcomes: Indicators directly pointing to the extent of self-reliance within the refugee community

The main requirements for the CPI were: (I) It must be easy to use for practitioners and academia, (II) it must contain standard quality criteria, like relevance, accuracy, timeliness, accessibility, interpretability, coherence, where appropriate (OECD 2008, pp.46-48) and (III) it must be adapted from existing tools to increase the probability of available and thus applicable indicators.

\section{STRENGTHS AND WEAKNESSES OF ATTEMPTS TO MEASURE SELF-RELIANCE}

Besides the rather broad definition given by UNHCR (2014) of self-reliance, the question is which fields, categories and indicators are necessary to judge if a person or a household is selfreliant or only engaged in livelihood opportunities. To assess this question, different initiatives have taken different paths. The Self-Reliance Initiative, for instance, has identified 12 domains 
including one or two questions for interviews of refugees (RefugePoint 2020). The conceptual framework (Betts et al. 2018; 2020) consists of Self-reliance Enabling factors and Self-reliance Outcomes, includes economic activities, investments/contributions, development and humanitarian aid, but also dependence. To assess self-reliance based on this framework, the research team interviews refugees and summarises the results as empirical findings.

The CPI comprises of nine categories including 109 indicators plus sub-indicators and thus is more extensive than the other two tools. As the CPI almost exclusively consists of already existing indicators - many coming from UNHCR sources ( $c f$. Supporting Information A: CPI system), information can be collected desk-based by scanning available publications in a structured way, guided by the indicator set. Additionally, but only if enough and accurate data is available, the number of indicators allows researchers and practitioners to identify where weaknesses exist that prevent self-reliance. Despite these advantages and depending on the context, the size of the CPI has further strengths, but also weaknesses:

$\underline{\text { Strengths in comparison to other tools: }}$

- The CPI is a generic tool - it does not aim to measure the objectives of a single organisation; it rather depicts if the combined inter-agency efforts of all organisations working in a camp bring a positive outcome: a higher self-reliance level.

- As the CPI is based almost exclusively on existing indicators (thereof, 83 indicators from UNHCR sources), they should be considered useful. It is likely that the indicator was measured before and is accessible.

- It not only focuses on assessing the households' level of self-reliance as, for instance, the Self-Reliance Index, but also on the organisational level (e.g., indicators on crisis management and partnerships - \#99-109).

- Relevant indicators of 11 tools, reports and concepts are included in the CPI (see Table 1). The results coming from these tools can be transferred easily into the CPI. 
- It does not compute indices and thus, is more transparent, easy to understand and to use without further background information.

- Even if only a fraction of the 109 indicators can be found, statements regarding the level of self-reliance can be extracted ( $c f$. Borchert 2019, Kunst 2020).

\section{$\underline{\text { Weaknesses in comparison to other tools }}$}

- The CPI is not usable as interview guideline (here SRI and/or conceptual framework by Betts et al. 2020 are more useful).

- "Guesstimating", assumptions and adaptions (e.g., from country level to camp level) must be made when online data quality and quantity is poor.

- By not computing indices, cross-camp comparisons can only be conducted in a descriptive way.

These strengths and weaknesses were mainly revealed during the test phase based on the aforementioned studies of Borchert (2019) for Zaatari, Azraq and Dadaab as well as Kunst (2020) for Bidibidi and Nakivale.

\section{FINDINGS OF CROSS-CAMP ANALYSES}

For the case studies, more than 100 reports and publications were scanned desk-based of which data of 80 sources were included to cover a wide field of existing published information regarding these refugee camps/settlements (Supporting Information B: CPI and case studies). Before going into detail, each camp/settlement is shortly introduced. 


\section{$\underline{\text { Jordan - Zaatari Camp }}$}

In 2012, the Jordan government established Zaatari camp on a desert field close to the city of Mafraq, about a one-hour drive northeast from Amman and close to the Syrian border (Schön 2020). It has expanded over time and thus, grew like a city in a centralised manner, hosting a big market reachable by everybody. In June 2020, the number of camp inhabitants accounted to more than 77,000 inhabitants coming from Syria, mainly the Dar'ā region (UNHCR 2020e), a relatively stable number since mid-2014. In 2013, the camp witnessed its highest influx of more than 200,000 inhabitants at a time (UNHCR 2020c). Zaatari camp is the biggest refugee camp in Jordan.

\section{$\underline{\text { Jordan - Azraq Camp }}$}

The second biggest refugee camp in Jordan is Azraq camp, situated deeper in the desert, further away from major cities and infrastructure than Zaatari camp and 1.5 driving hours away from Amman. It was purposely planned and built in 2014 before inhabited. It is divided into five decentralised villages. The camp shelters about 41,000 Syrian refugees and faced its peak between 2016 and 2018, when about 54,000 people lived in the camp (UNHCR 2020d).

\section{$\underline{\text { Kenya - Dadaab }}$}

In 1991, the Kenyan government established Dadaab Complex, situated in the North-East in the Kenyan desert. Initially built for only 90,000 refugees, it faced its peak of influx in 2014 and meanwhile sheltered over 520,000 refugees (MacKinnon 2014). Due to a steady arrival of refugees, the complex evolved continuously and now consists of three camps which hold 217,511 refugees, mainly coming from Somalia and Ethiopia (UNHCR 2020a). 


\section{$\underline{\text { Uganda - Nakivale Refugee Settlement }}$}

Nakivale refugee settlement, located in a rural area in southwestern Uganda and officially recognized as a refugee settlement in 1960, is one of the oldest refugee settlements of the country (UNHCR 2019d). Its population of 132,700 refugees is greatly mixed, being composed of 15 different nations, with the majority of refugees from the Democratic Republic of Congo, Burundi, Somalia and Rwanda (GOU, OPM 2020). Nakivale settlement is clustered in three zones, covering an area of about $185 \mathrm{~km}^{2}$ (UNHCR Uganda 2014). The closest town Mbarara is about $60 \mathrm{~km}$ away (Ilcan, Oliver, Connoy 2015).

\section{$\underline{\text { Uganda - Bidibidi Refugee Settlement }}$}

In contrast, Uganda's largest refugee settlement Bidibidi in the North is giving shelter to a highly homogeneous refugee population: situated close to the South Sudanese borderline, refugees finding shelter in Bidibidi are almost exclusively from South Sudan (UNHCR 2020b). Rising from an area covered by forest, Bidibidi refugee settlement has been expanding tremendously since its opening in 2016 , hosting more than 280,000 refugees residing in five zones (UNHCR 2019d). The shortest distance to the closest town, Yumbe town, is about $13 \mathrm{~km}$ (UNHCR 2019a).

Following, each of the nine categories introduced in the CPI framework (Figure 1) including the main results of the cross-camp analyses are summarised. The full list of indicators as well as case study findings is included in Supporting Information B. More details for each category as well as the justifications of each indicator are listed in Supporting Information A. 


\section{$\underline{\text { Demographic Data }}$}

Demographic data needs to be gathered to know who lives in the camp under which conditions related to the ability to become self-reliant. All indicators here belong to group A (exogenous factors). Our case studies show that data availability is good regarding general data about age and gender, but is less clear on more explicit data, such as disability. Here data do not reveal which kind of disabilities are included (physical and/or psychological challenges) or the dependency ratio ( $c f$. indicators in Supporting Information B: \#3, \#5). Further, some sources count disabled people, others count households having a disabled or chronically ill person at home (UNHCR 2018c; REACH 2019). The data on adult education (\#11-13) could not be obtained, but should be made available as it is important to know the level of schooling, knowledge and skills of the inhabitants to plan and implement livelihood initiatives. Available data points at a general low level of education within the researched camps and thus, a high need of targeted services regarding training and advice. In general, reaching self-reliance becomes more difficult when the level of education is low. For the camp management is clear: the more they know about the living circumstances of the camp inhabitants, the more purposefully they can act (Schön 2020). The cross-camp comparison of demographic data reveals that almost $40 \%$ (mean value of all inhabitants age 18-59) of the camp inhabitants could be counted as potential labour force if not disabled, injured, ill and traumatised, newly arrivals, pregnant and young mothers or, partly, single parenting, which cannot be extracted from available data.

\section{$\underline{\text { Basic needs }}$}

In comparison to other categories, the data availability of the category Basic Needs is quite good. Comparing the five case studies with each other is nearly impossible, though, as standards regarding basic needs highly differentiate. Whereas the standards in Zaatari camp regarding food, drinking water, WASH, and electricity are relatively high, standards in Dadaab camp are 
rather poor (e.g., \#29 “Time to collect drinking water" 1 or more hours: 48\% and \#45 "Population with access to a sufficient, balanced diet without assistance": less than 50\%; (REACH 2018b)). The same applies to Bidibidi and Nakivale in Uganda (e.g., \#28 "Population with access to enough basic drinking water services": $56 \%$ in Bidibidi, 26\% in Nakivale in 2018 (REACH 2018a, 2018c)). Data inaccuracy is illustrated by \#29b and \#29c for Bidibidi. The cited UNHCR report only states that people need up to and more than one hour to fetch drinking water, but not what percentage actually needs more than 2 hours to collect drinking water (UNHCR et al. 2016). Basic Needs indicators belong to group A or B.

\section{Camp Funding}

Data availability on Camp Funding indicators is low, although most were taken from UNHCR sources. Most indicators belong to group B (enabling factors), because the more funding a camp has, the better equipped is the management to facilitate livelihood opportunities by giving out essential financial (e.g., loans), tangible (e.g., equipment, electricity) or intangible (e.g., education, training and advice) resources. Data availability on education is very low and partly difficult to compare. For instance, although being an UNHCR indicator, the only data found for \#21 "Population of working-age receiving life-skills training for livelihood purposes" refers to agricultural practices in the Ugandan camps and were taken from an UNHCR source (3\% of the total refugee population in Bidibidi, but $11 \%$ in Nakivale (UNHCR 2018a, 2018b)). In some cases, the comparability of indicators is impossible, for instance, when each report has created its own indicators. Indicator \#42 asks for "Households receiving cash/vouchers for agriculture/livestock purposes". The only indicators found were "Cash/vouchers for livelihood provisioning” for Bidibidi and Nakivale (UNHCR 2018a, 2018b). It remains unclear, if each household is given only one voucher/only once cash for livelihood provisioning and how many of the households which have received cash/vouchers actually use it for agriculture/livestock purposes 
or for other livelihood provisioning. As agriculture is especially promoted as livelihood provisioning in Uganda, can we assume that at least most cash/vouchers were given out for agriculture purposes, especially if we look at the high number of production kits or inputs for agriculture activities, at least for Bidibidi (\#41)?

Indicators such as \#45 "Population with access to a sufficient, balanced diet without assistance" aim at counting only residents not in need of cash, vouchers, Bamba Chakula, etc. However, in all assessed camps, inhabitants are supported in some way, making it difficult to judge who at least could feed his/her household without assistance. Ergo, this indicator could belong to B, if assistance for food helps enabling self-reliance (people are not hungry and thus have more strength to work), or to $\mathrm{C}$ (outcomes), if it shows the outcome of self-reliance measures.

\section{Camp Location}

Most camps, including Azraq, Dadaab and Bidibidi, are located in economically poor, arid areas with little natural resources available (Kunst 2020; Schön 2020; Borchert 2019). Reasons for this are mainly of political nature (Schön 2020). Though camp management has little influence of this situation, it still can improve lives of the inhabitants by integrating suitable interventions. Thus, most indicators of this category have been grouped to C. Assessing the little data available, the locations of the studied camps appear to have a negative impact on the refugees, except perhaps Nakivale being located in wetlands (UNDP 2017) (cf. \#48 "Households engaged in some form of income generation based upon local resources or assets" in Nakivale (indicator used here: "Out of the $64 \%$ of HHs who reported having a source of income", farming: $45 \%$ ) (REACH et al. 2019b)). 


\section{$\underline{\text { Legal Issues }}$}

Only little data could be obtained for the category Legal Issues. Still, the picture is quite clear: In Kenya it has become difficult to obtain a work permit at all and movement is restricted (Wesangula 2016; International Rescue Committee 2018). In Uganda, besides flaws within the Self-Reliance Strategy (SRS), refugees are allowed to move and work and get allocated a plot of land to farm (Betts et al. 2019; Hovil 2018). In Jordan, the situation has improved much since the Jordan Compact was introduced in 2016 - even camp-based refugees can obtain a work permit, though restricted to certain sectors (especially agriculture and construction), and are allowed to move freely with a work permit (Gray Meral 2020; Schön 2020). Most indicators identified for the CPI were clustered to group B or C whereby assumptions were made for the grouping: \#85 "Business paying taxes", for instance, is grouped to C, assuming that business owners are allowed to operate their business legally and only then pay official taxes for which in turn security and benefits are provided by the government.

\section{$\underline{\text { Social Capital }}$}

In many countries, social networks and social institutions are the only way to engage successfully in livelihood activities (UNHCR 2005). Social capital is important for economic, political, financial, or simply social purposes. It can consist of networks used for business opportunities or to strengthen the rights of the network and is set up by organisations, refugees or hosts (Schön 2020). For the case studies, only very limited data was obtained for Social Capital indicators. In Bidibidi, about 68\% of the residents put cash in savings groups (\#80) (MicroFinanza 2018), participate either in village savings and loan associations $(43 \%)$ or in farmer's groups $(32 \%)$ (REACH et al. 2019a). In Nakivale these figures are much lower: 19\% participate in village savings and loan associations, 10\% in farmer's groups (REACH et al. 2019b), and only 39\% put cash in savings groups (MicroFinanza 2018). Indicators either belong to group A, especially 
when reflecting the degree of social safety nets people have, or to group B, when refugees participate in cooperatives, production groups and community-based organisations (\#34, \#35, \#60, \#80-82) usually implemented/facilitated by aid organisations, micro finance institutions, etc.

\section{Children's Education and Political Voice, Gender Equality}

For the category Gender Equality, no data was found for the respective indicators. Indicators belong to group $\mathrm{A}$ or $\mathrm{B}$, but different measures within a camp can actually improve gender equality, if change is coming from within (Schön 2020). Gender equality is an essential topic as globally, countries are losing USD 160 trillion in wealth due to lifetime earning differences of men and women, amounting to USD 23,620 for each person in the 141 countries analysed by the World Bank Group (The World Bank 2018b). Through employment, women (and men) can increase their political and civic participation, also because only then they can prove that they are capable to lead and perform just as well as men (The World Bank 2013). Examples like the UN Women Oasis centres in Zaatari camp can highly contribute to strengthening women, their rights and getting them into employment (UN Women 2019). Children's education, although of high importance for the level of self-reliance in the next generation, is not essential to measure self-reliance for the current adult inhabitants. Thus, this category is mainly left out in the CPI System, although it is generally of great importance.

\section{Employment and Income}

This category consists of group C indicators. Its objective is to sum up how many people actually are or would be able to live self-reliantly, meaning that they can pay bills by income or could come up with emergency funds by income (\#40a). If enough data was available, the so- 
called Employment Matrix could be filled out to compare different camps (Schön 2020). The Employment Matrix is a matrix stating which age group (male/female) is in formal or informal employment, self-employed or unemployed, part-time or full-time on an open-ended, temporary, irregular/seasonal or unsteady period, employed by a NGO, in the camp or outside the camp (Schön 2020, p.90). For these case studies however, neither data for the relevant indicators nor the Employment Matrix could be obtained.

\section{THE WAY TOWARDS MORE SELF-RELIANCE IN REFUGEE CAMPS}

Comparing all case studies in a general matter, none of the camps/settlements stands out in all categories. In Jordan, for instance, restrictions on freedom of movement for those without a work permit affect the access to markets as well as professional and educational opportunities, which is intensified by a remote location of the camps, especially Azraq camp. Concerning latter, strict policies impede self-reliance here almost completely (Schön 2020). In Kenya, refugees' rights are restricted the most. Living in an isolated, arid location, self-reliance is out of reach for many Dadaab residents, who remain dependent on humanitarian agencies - although these are financially not able to cover the refugees' basic needs ( $c f$. Supporting Information B: indicators on basic needs). If generating an income, it is in general too small to lead to selfreliance according to the definition of UNHCR (2014). In Uganda, policies are progressive, although not flawless (Betts et al. 2019). Conditions in the settlements ought to improve towards more job opportunities, a functioning and affordable transportation network and greater access to capital for the start-up and expansion of businesses. Owing to the impracticality of agriculture for achieving self-reliance, the government should reconsider its assistance programme and also support alternative livelihood opportunities, more feasible for generating a proper income. 
The findings of our case studies as well as provided literature support the following recommendations mainly addressed to the donor community and local governments:

- Human rights, especially the freedom to move and to work, ought to be respected for all refugees around the world.

- Infrastructure needs to be made available and accessible, even more when camps are located outside of markets, otherwise, human rights cannot be enjoyed, even if granted.

- Local labour markets need to be available and access must be granted and made possible.

We are convinced that self-reliance cannot be achieved for encamped refugees as long as these recommendations are ignored. Thus, camps and settlements, if they cannot be avoided, should be set up close to existing markets. By simultaneously providing sufficient training, start-up capital for businesses and affordable means of transportation to purchase relevant items at markets, refugees and hosts can find niches in markets and take up economic activities apart from farming, illegal and informal work. 


\section{CONCLUSION}

We collected data on five refugee camps/settlements in Jordan, Kenya and Uganda to test the developed Camp Performance Indicator system as well as to assess the level of self-reliance for these case studies in a structured way. By testing the usefulness of the CPI, we faced significant limitations on data availability for all case studies, even though the CPI System is based only on existing indicators, many of them UNHCR sourced. It remains unclear why data availability as well as accuracy for UNHCR indicators is so low and why each report measures its own indicators. Does UNHCR only recommend that its field operators measure the indicators published in guidelines, but leave country officers considerable leeway in adapting these indicators or even in developing own ones? Is data available within the organisation but not published? Until these circumstances of data unavailability and inaccuracy is not improved and published by aid agencies, desk-based research remains limited as can be seen for present study.

Despite these challenges, we conclude that the CPI consisting of 109 indicators (plus sub-indicators) is extensive and flexible enough to derive overall statements of the level of self-reliance within a camp or settlement as done by Borchert (2019) and Kunst (2020).

The mixed-method approach of a quantitative data collection and a qualitative analysis/interpretation of the results supports our hypothesis that the level of self-reliance for all case studies, including Zaatari camp, probably the most modern camp in the world, is low and will remain so if refugee policies do not change significantly towards more integration of this group. On the one hand, a note of caution is due here since findings remain somewhat limited as the interpretation of the data set is of qualitative nature, because the CPI does not provide a computed index. On the other hand, caution must also be applied when assessing a camp only by including quantitative data, as non-measurable/qualitative factors, such as power relations or gender equality ( $c f$. Schön (2020)), are ignored. 
As none of the case studies could indicate a high level of self-reliance, questions about the real intentions of certain stakeholder groups can be raised: Why is the funding level chronically too low? Why is the donor community not cooperating better with the host governments which account to the poorest countries in the world and do not possess sufficient resources to adequately support both its citizens and refugees? Further research is required regarding the evergrowing funding gap and the impact of accurate measures on self-reliance of refugees and hosts, including the refugees' decision to stay in the host country, return home or even emigrate to a Western country.

\section{REFERENCES}

ABDI, A. M. (2008): In Limbo: Dependency, Insecurity, and Identity amongst Somali Refugees in Dadaab Camps. Bildhaan: An International Journal of Somali Studies, 5, 17-34.

ALNAP (2015): The State of the Humanitarian System. London.

BETTS, A. (2014): Refugee Economies: Rethinking Popular Assumptions.

BETTS, A., CHAARA, I., OMATA, N., STERCK, O. (2019): Uganda's Self-Reliance Model: Does it Work?

BETTS, A., GEERVLIET, R., MACPHERSON, C., OMATA, N., RODGERS, C., STERCK, O. (2018): Self-Reliance in Kalobeyei?: Socio-Economic Outcomes for refugees in North-West Kenya. Oxford RSC.

BETTS, A., OMATA, N., STERCK, O. (2018): Refugee Economies in Kenya. Refugee Studies Centre Oxford.

BETTS, A., OMATA, N., STERCK, O. (2020): The Kalobeyei Settlement: A Self-reliance Model for Refugees? Journal of Refugee Studies, 33, 1, 189-223.

BORCHERT, C. (2019): Einfluss der Infrastruktur und Services von Flüchtlingscamps auf das 'Level of Self-Reliance' von Flüchtlingen: ein kritischer Vergleich von Fallstudien in Zaatari, Azraq und Dadaab. Fulda.

BULLEY, D. (2017): Migration, ethics \& power: spaces of hospitality in international politics. Sage, Los Angeles, London, New Delhi, Singapore, Washington DC, Melbourne.

CORBET, A. (2016): Community After All?: An Inside Perspective on Encampment in Haiti. Journal of Refugee Studies, 29, 2, 166-186.

DIKEN, B. (2004): From Refugee Camps to Gated Communities: Biopolitics and the End of the City. Citizenship Studies, 8, 1, 83-106.

EASTON-CALABRIA, E., OMATA, N. (2018): Panacea for the refugee crisis? Rethinking the promotion of 'self-reliance' for refugees. Third World Quarterly, 39, 8, 1458-1474. 
FIELD, J., TIWARI, A. D., MOOKHERJEE, Y. (2020): Self-reliance as a Concept and a Spatial Practice for Urban Refugees: Reflections from Delhi, India. Journal of Refugee Studies, 33, 1, 167-188.

GOU, OPM (2020): Uganda - Active population by settlement May 2020.

GRAY MERAL, A. (2020): Assessing the Jordan Compact One Year On: An Opportunity or a Barrier to Better Achieving Refugees' Right to Work. Journal of Refugee Studies, 33, 1, 42-61.

HOVIL, L. (2018): Uganda's refugee policies: The history, the politics, the way forward.

HUNTER, M. (2009): The Failure of Self-Reliance in Refugee Settlements. Polic Journal, 2, Winter, $1-46$.

ILCAN, S., OLIVER, M., CONNOY, L. (2015): Humanitarian assistance and the politics of self-reliance: Uganda's Nakivale refugee settlement.

INTERNATIONAL RESCUE COMMITTEE (2018): Dreams Deterred. Kenya.

JAHRE, M., KEMBRO, J., ADJAHOSSOU, A., ALTAY, N. (2018): Approaches to the design of refugee camps. Journal of Humanitarian Logistics and Supply Chain Management, 8, 3, 323-345.

KAISER, T. (2006): Between a camp and a hard place: rights, livelihood and experiences of the local settlement system for long-term refugees in Uganda. The Journal of Modern African Studies, 44, 4, 597-621.

KUNST, L. (2020): Self-Reliance of Refugees in Uganda: A Comparison of Bidibidi and Nakivale Refugee Settlement. Fulda.

LEESON, K., BHANDARI, P. B., MYERS, A., BUSCHER, D. (2020): Measuring the Self-Reliance of Refugees. Journal of Refugee Studies, 33, 1, 86-106.

MACKINNON, H. (2014): Education in Emergencies: The Case of the Dadaab Refugee Camps: Policy Brief.

MICROFINANZA (2018): Assessing the needs of refugees for financial and non-financial services - Uganda: Final report.

NEELY, A., GREGORY, M., PLATTS, K. (1995): Performance measurement system design. International Journal of Operations \& Production Management, 15, 4, 80-116.

OECD (2008): Handbook on Constructing Composite Indicators: Methodology and User Guide. OECD Publishing.

OSCHMIANSKY, F. (2010): Folgen der Arbeitslosigkeit | bpb, http://www.bpb.de/politik/innenpolitik/arbeitsmarktpolitik/54992/folgen-der-arbeitslosigkeit?p=all (5.2.2017).

REACH (2018a): Multi-Sector Needs Assessment: Bidibidi Settlement: Yumbe District, Uganda.

REACH (2018b): Multi-Sector Needs Assessment: Dadaab Refugee Complex: Garissa County, Kenya.

REACH (2018c): Multi-Sector Needs Assessment: Nakivale Settlement: Isingiro District, Uganda.

REACH (2019): Multi-sector Needs Assessment: Dadaab Refugee Complex, Garissa country, Kenya.

REACH, NRC, EU CIVIL PROTECTION AND HUMANITARIAN AID (2019a): Refugee access to livelihoods and housing, land and property: Bidibidi settlement factsheet 2019.

REACH, NRC, EU CIVIL PROTECTION AND HUMANITARIAN AID (2019b): Refugee access to livelihoods and housing, land and property: Nakivale settlement factsheet 2019.

REFUGEPOINT (2020): Refugee Self-Reliance Initiative, https://www.refugeeselfreliance.org/ (13.11.2020). 
ROUSE, P., PUTTERILL, M. (2003): An integral framework for performance measurement. Management Decision, 41, 8, 791-805.

SCHÖN, A.-M. (2020): Assessing the Level of Self-Reliance and Livelihood of Encamped Refugees Focusing on Syrian Refugees in Jordan.

SCHÖN, A.-M., AL-SAADI, S., GRUBMUELLER, J., SCHUMANN-BÖLSCHE, D. (2018): Developing a camp performance indicator system and its application to Zaatari, Jordan. Journal of Humanitarian Logistics and Supply Chain Management, 5, 8, 17.

SKRAN, C., EASTON-CALABRIA, E. (2020): Old Concepts Making New History: Refugee Selfreliance, Livelihoods and the 'Refugee Entrepreneur'. Journal of Refugee Studies, 33, 1, 1-21.

SLAUGHTER, A. G. (2019): Fostering Refugee Self-reliance: A Case Study of an Agency's Approach in Nairobi. Journal of Refugee Studies, 41, 3, 9.

THE HUNGER PROJECT (2018): Measuring Self-Reliance, http://www.thp.org/our-work/where-wework/africa/epicenter-strategy/measuring-self-reliance/ (27.4.2018).

THE WORLD BANK (2013): Opening doors: gender equality and development in MENA.

THE WORLD BANK (2018a): DataBank, http://databank.worldbank.org/data/home.aspx (12.6.2018).

THE WORLD BANK (2018b): Globally, Countries Lose \$160 Trillion in Wealth Due to Earnings Gaps Between Women and Men.

TURNER, S. (2016): What is a Refugee Camp?: Explorations of the Limits and Effects of the Camp. Journal of Refugee Studies.

UN WOMEN (2019): Strengthening resilience, investing in passion: Zonta International Foundation and UN Women empower women across Jordan.

UNDP, U. I. (2017): Isingiro District: Investment Profile.

UNHCR (2005): UNHCR Handbook for Self-reliance.

UNHCR (2012): Livelihood Programming in UNHCR: Operational Guidelines.

UNHCR (2014): Global Strategy for Livelihoods: A UNHCR Strategy 2014-2018.

UNHCR (2018a): Uganda Refugee Response Monitoring: Settlement Fact Sheet: Bidi Bidi.

UNHCR (2018b): Uganda Refugee Response Monitoring: Settlement Fact Sheet: Nakivale.

UNHCR (2018c): Jordan: Azraq Refugee Camp: Fact Sheet.

UNHCR (2019a): Bidibidi refugee settlement, Yumbe District: Draft as of 16th of May 2019.

UNHCR (2019b): Global Trends: Forced Displacement in 2018.

UNHCR (2019c): Operational Portal Refugee Situation: Zaatari Camp.

UNHCR (2019d): Refugee Access to Livelihoods and Housing, Land, and Property: Uganda.

UNHCR (2020a): Kenya Statistics Package: Statistical Summary.

UNHCR (2020b): Refugees and asylum-seekers in Uganda: Uganda Refugee Response 31-May-2020.

UNHCR (2020c): Situation Syria Regional Refugee Response: Zaatari Camp.

UNHCR (2020d): Syria Regional Refugee Response: Azraq Camp.

UNHCR (2020e): Zaatari Refugee Camp - Factsheet, May 2020.

UNHCR, UNICEF, DRC, OXFAM, NRC (2016): WASH knowledge, attitude and practice (KAP) survey report: Bidibidi settlement, Yumbe district. 
UNHCR UGANDA (2014): Nakivale: Fact Sheet.

UNITED NATIONS ECONOMIC AND SOCIAL COUNCIL (2016): General Comment No. 23 (2016).

USA FOR UNHCR (2020): Refugee Camps.

VAN DAMME, W. (1995): Do refugees belong in camps?: Experiences from Goma and Guinea. Lancet.

WERKER, E. (2002): Refugees in Kyangwali Settlement: Constraints on economic freedom. Refugee Law Project, Kampala, Uganda.

WERKER, E. (2007): Refugee Camp Economies. Journal of Refugee Studies, 20, 3, 461-480.

WESANGULA, D. (2016): Dadaab: the city you cannot leave. Nairobi.

WOMEN'S REFUGEE COMMISSION (2009): Building Livelihoods: A Field Manual for Practitioners in Humanitarian Settings. New York.

YOUNG, I. M. (1992): Five faces of oppression. In: Wartenberg, T. E. (ed.): Rethinking power. State University of New York Press, Albany, N.Y., 174-195.

YUNUS, M. (2018): World of Three Zeros: The new economics of zero poverty, zero unemployment, and zero net carbon... emissions. PUBLIC AFFAIRS, [S.1.]. 
Table 1: Sources influencing CPI

These 11 sources have been included in the CPI. No. 12 indicates that the number of indicators has slightly changed to fit into the camp context. The third column shows how many indicators each source contains. The fourth column displays the number of indicators which were included from each source; double counting possible.

\begin{tabular}{|c|c|c|c|}
\hline No. & Source & $\begin{array}{l}\text { No. of indicators } \\
\text { available in source }\end{array}$ & $\begin{array}{l}\text { No. of indicators }(+ \\
\text { sub-indicators) in- } \\
\text { fluencing the CPI }\end{array}$ \\
\hline 1 & The World Bank (2018a), "DataBank" & $\begin{array}{l}133 \text { (with possible } \\
\text { camp-context from } \\
\text { originally } 2,721 \text { in- } \\
\text { dicators of four } \\
\text { data bases) }\end{array}$ & 27 \\
\hline 2 & $\begin{array}{l}\text { RefugePoint (2019), "Refugee Self-Reliance } \\
\text { Initiative" }\end{array}$ & $\begin{array}{l}\text { Biographic Infor- } \\
\text { mation excluded, } \\
14 \text { domains, plus } 2 \\
\text { to } 7 \text { reply options } \\
\text { each }\end{array}$ & 6 \\
\hline 3 & $\begin{array}{l}\text { JIPS (2018b), "Indicator library. Durable Solu- } \\
\text { tions" }\end{array}$ & 125 & 19 \\
\hline 4 & $\begin{array}{l}\text { Betts et al. (2018), "Refugee Economies in } \\
\text { Kenya" }\end{array}$ & $\begin{array}{l}\text { Approx. } 43 \text { (fig- } \\
\text { ures, tables and de- } \\
\text { scriptive text) }\end{array}$ & 6 \\
\hline 5 & $\begin{array}{l}\text { The Hunger Project (2018), "Measuring Self- } \\
\text { Reliance" }\end{array}$ & About 50 & 5 \\
\hline 6 & $\begin{array}{l}\text { Women's Refugee Commission (2009), } \\
\text { "Building Livelihoods. A Field Manual for } \\
\text { Practitioners in Humanitarian Settings" }\end{array}$ & $\begin{array}{l}\text { No clear indicators } \\
\text { available, but de- } \\
\text { rived from descrip- } \\
\text { tive text and ques- } \\
\text { tions }\end{array}$ & 8 \\
\hline 7 & $\begin{array}{l}\text { UNHCR (2014), "Global Strategy for Liveli- } \\
\text { hoods: A UNHCR Strategy 2014-2018" }\end{array}$ & $\begin{array}{l}48 \text { indicators of } \\
\text { achievement }\end{array}$ & 30 \\
\hline 8 & $\begin{array}{l}\text { UNHCR (2012), "Livelihood Programming in } \\
\text { UNHCR: Operational Guideline" }\end{array}$ & About 57 & 26 \\
\hline 9 & $\begin{array}{l}\text { UNHCR (2005), "UNHCR Handbook for Self- } \\
\text { reliance" }\end{array}$ & $\begin{array}{l}\text { About } 49 \text { (Toolkit, } \\
\text { Figure 10) }\end{array}$ & 12 \\
\hline 10 & $\begin{array}{l}\text { UNHCR (2019c), "Operational Portal Refugee } \\
\text { Situation. Zaatari Camp" }\end{array}$ & $\begin{array}{l}5 \text { (focus on demo- } \\
\text { graphic data) }\end{array}$ & 5 \\
\hline 11 & $\begin{array}{l}\text { Betts et al. (2018), "Self-Reliance in Ka- } \\
\text { lobeyei?: Socio-Economic Outcomes for refu- } \\
\text { gees in North-West Kenya" }\end{array}$ & $\begin{array}{l}\text { Approx. } 58 \text { (fig- } \\
\text { ures, tables and de- } \\
\text { scriptive text) }\end{array}$ & 35 \\
\hline 12 & $\begin{array}{l}\text { Indicator added or changed by author on the } \\
\text { basis of self-reliance camp context }\end{array}$ & & 7 \\
\hline
\end{tabular}

